\title{
AMINO ACID VARIATIONS IN URINE OF URINARY TRACT INFECTION PATIENTS
}

\author{
Muhammad Ali Memon, Habibullah Quershi and M. Saleh Memon
}

\begin{abstract}
BACKGROUND/OBJECTIVES: Majority of urinary tract infection (UTI) patients received at Liaquat University Hospital Jamshoro and Hyderabad belong to adjoining rural areas of Sindh province. As only reliable clinical laboratory test available for diagnostic purpose is urine culture and sensitivity which is lacking in these areas due to complexity of tests, expertise and non-availability of electric facility. Hence, present study was conducted to device alternate method, which must be simple, easy and does not require much expertise.

PATIENTS AND METHODS: In all, 106 patients and 25 normal controls were selected for this study. Morning urine samples were collected and analyzed for amino acids by paper chromatography using two different solvent systems.

RESULTS: Different amino acids were found missing in urine of UTI patients. Greater percent of them was aromatic amino acids like tryptophan (90.56\%), phenylalanine $(71.69 \%)$, tyrosine $(\mathbf{7 0 . 7 5 \% )}$ and methionine (91.5\%).

CONCLUSION: Ordinary urine chromatographic separation test of amino acids shows aromatic and essential amino acids absent from urine, which can provide basis for screening test of UTI in areas with lesser facilities.
\end{abstract}

KEY WORDS: Amino acids. Urinary tract infection. Chromatography. Aromatic amino acids. Essential amino acids.

\section{INTRODUCTION}

Urinary tract infection (UTI) is one of the most common infections seen in day to day practice. ${ }^{1,2}$ Women are more commonly affected showing prevalence of about $3 \%$ at age of 20 , increasing by $1 \%$ in each subsequent decade ${ }^{3}$ while in males UTI is less common in younger age group but can develop a serious course when it does occur. ${ }^{4}$ After 60 years of age, UTI becomes common in males due to prostate hypertrophy. UTI causes considerable morbidity and even renal damage. It may lead to chronic renal failure in small minority of cases. ${ }^{3}$ Urinalysis is most commonly used test for evaluation of patients with potential UTI. Urinalysis is done by dipstick and microscopic examination of urine. However, diagnostic accuracy of these tests is debatable.$^{5-7}$ In clinically positive cases of UTI, a negative dipstick is of no significance. ${ }^{8}$ This test is a poor predictor of proteinuria and hematuria. ${ }^{9}$ Nitrite and leucocyte estrase miss significant microscopic findings with corresponding clinical pathology. ${ }^{10}$ Other reliable investigation in UTI is culture/sensitivity $(\mathrm{C} / \mathrm{S})$ which is performed on voided urine to identify pathogen bacteria and their antimicrobial sensitivity patterns. ${ }^{11}$ Due to widespread misuse of antibiotics, most of C/S reports show no growth. Radiography, IVP, ultrasonography and CT scan are recent and accurate investigations ${ }^{12}$ but these require advanced tools, electric facility beside technical and expert as- sistance, which is not available in rural areas in Sindh. Hence, a need was felt to develop a simple procedure to diagnose UTI more easily with less expertise, minimum laboratory requirements and low cost. In previous studies on parasitic infested rats, selected amino-acids were found decreased in plasma as compared to normal rats. ${ }^{13}$ We planned to study the amino-acid variations in urine of UTI patients.

\section{PATIENTS AND METHODS}

This study was conducted on 106 patients admitted in different wards of Liaquat Hospital Jamshoro and Hyderabad. Patients were diagnosed on the basis of urine detailed report and urine culture and sensitivity.

Sample collection:1st morning samples of urine were collected from patients and controls. Subjects were supplied with clean sterilized bottles, with the instruction to wash groin with soap and water and then put mid stream urine in the bottles. In small children who were not yet toilet trained, plastic collection bags were placed at the genital area. Elder children were asked to urinate in containers. Samples were transported immediately to laboratory and processed promptly. In case of delay, samples were stored at $4^{\circ} \mathrm{C}$ and were analyzed within two hours of collection. Samples were used for urine detailed report (DR) i.e. volume, colour, appearance, $\mathrm{pH}$, specific gravity, albumin, sugar, ketone bodies, bile salts, and bile pig- 
ments. These were also used for $\mathrm{C} / \mathrm{S}$ as well as for amino acid analysis by paper chromatography. Chemical examination was done by dipstick Multistix 8 (Ames division, Miles Inc. USA, Division of Bayer Australia Ltd.). ${ }^{14}$ Presence of blood, protein, nitrite and leucocyte esterase indicated a positive urine sample, that confirmed the presence of infection. Microscopic examination of urine wet film was also done. ${ }^{11} \mathrm{~Pa}-$ tients having equal to or more than $10^{4}$ or more leucocytes per $\mathrm{ml}$ were labeled positive for this criteria. Urine culture was done by conventional method ${ }^{11}$ on blood and MacConkey agar (without salt). Plates were examined after 24 hours of incubation aerobically at $37^{\circ} \mathrm{C}$. Number of colony forming units (CFU) were calculated. Bacterial count $10^{5} \mathrm{CFU} / \mathrm{ml}$ or more indicated infection. ${ }^{15}$ Bacterial identification was performed accordingly. ${ }^{16,17}$

\section{Paper chromatography for amino acids in urine:}

This method is used in UK for screening of Phenylketonuria and other amino acid disorders in newborns. ${ }^{18}$ Wattman's paper number 1 was used for chromatography. To avoid any overlapping of amino acids, we used two solvent systems.

Solvent no.1: n - Butanol:Acetic acid: water ratio 4:1:5. Solvent no. 2: $n$ - Butanol: Pyridine: water ratio 1:1:1.

Chromatographic paper was applied seven times with help of capillary tube dipped in amino acid standard, infected and normal urine samples and then these papers were hanged in Jars of solvent and kept there till solvent ascended to $15 \mathrm{~cm}$ height. Dried it in air spread with ninhydrin reagent then kept it on hot oven at $100-105^{\circ} \mathrm{C}$ for ten minutes. Mark the colour spots seen on paper with pencil and calculate $R_{f}$ value (resistance against force) of amino acids as under:

$$
R_{f}=\frac{\text { Distance traveled by solute }}{\text { Distance traveled by solvent }}
$$

Amino acids were identified by $R_{f}$ values. ${ }^{19,20}$ Radiology tests were performed to establish UTI. All investigations i.e. urinalysis, urine $\mathrm{C} / \mathrm{S}$, radiology and ultrasound were performed at Liaquat University Hospital Jamshoro and Hyderabad. Paper chromatography was carried out at Laboratory of Biochemistry, University of Sindh Jamshoro. Informed consent was obtained from all the subjects enrolled in study.

\section{RESULTS}

Among study subjects, there were 42 males, 42 females, 22 children (19 boys and 9 girls) and 25 matching normal persons as control group including 10 males, 10 females and 5 children.

Table-I shows mean age, urine dipstick and microscopic examination findings of the patients. Urine dipstick and microscopic examination pattern of positive percentage of patients was same in all age groups. Thirty-eight patients had albumin + positive, 23 had albumin ++ and 7 had +++ positive, 19 patients had WBC 10-20/HPF (High Power Field of microscope $X$ 40), while 73 patients had more than 20/HPF. Twentynine patients had 2-10 RBCs/HPF, while 61 had more than 10 RBCs/HPF. Table-II shows data of amino acids absent in urine of patients and controls. The number of missing aromatic amino acids was very high i.e. tryptophan was missing in 96(90.56\%), phenylalanine in $76(70.69 \%)$ and tyrosine in 75 (70.75\%) cases. Among the other amino acids, it was methionine in 97 $(91.50 \%)$ cases, isolucine was missing in $70(66.03 \%)$, aspartic acid in 55 and proline in 53 cases. In urine of control subjects, phenylalanine was missing in 2 cases; tryptophan in 4 cases and tyrosine in 3 cases while other amino acids aspartate, asparagine, glutamate and threonine in 1,2, 2 and 6 cases respectively.

TABLE I:

FINDINGS OF DIPSTICK AND MICROSCOPIC URINALYSIS IN DIFFERENT AGE GROUPS

\begin{tabular}{|c|c|c|c|c|c|c|c|c|}
\hline & \multirow{2}{*}{$\frac{\text { Age }}{\text { (mean years) }}$} & \multicolumn{3}{|c|}{ Albumin } & \multicolumn{2}{|c|}{ WBCs } & \multicolumn{2}{|c|}{ RBCs } \\
\hline & & + & ++ & +++ & $10-20^{\dagger}$ & $>20^{\dagger}$ & $2-10^{\dagger}$ & $>10^{\dagger}$ \\
\hline $\begin{array}{l}\text { Children } \\
(n=22)\end{array}$ & $\begin{array}{r}6.45 \\
\pm 2.46\end{array}$ & $\begin{array}{c}12 \\
(54.55 \%)\end{array}$ & $\begin{array}{c}2 \\
(9.1 \%)\end{array}$ & $\begin{array}{c}\text { Nil } \\
(0 \%)\end{array}$ & $\begin{array}{c}5 \\
(22.73 \%)\end{array}$ & $\begin{array}{c}15 \\
(68.18 \%)\end{array}$ & $\begin{array}{c}5 \\
(2.73 \%)\end{array}$ & $\begin{array}{c}12 \\
(54.55 \%)\end{array}$ \\
\hline $\begin{array}{l}\text { Female } \\
(n=42)\end{array}$ & $\begin{array}{r}36.78 \\
+14.0\end{array}$ & $\begin{array}{c}12 \\
(28.57 \%)\end{array}$ & $\begin{array}{c}11 \\
(26.19 \%)\end{array}$ & $\begin{array}{c}5 \\
(11.90 \%)\end{array}$ & $\begin{array}{c}7 \\
(16.67 \%)\end{array}$ & $\begin{array}{c}33 \\
(78.57 \%)\end{array}$ & $\begin{array}{c}15 \\
(35.7 \%)\end{array}$ & $\begin{array}{c}23 \\
(54.76 \%)\end{array}$ \\
\hline $\begin{array}{l}\text { Male } \\
(n=42)\end{array}$ & $\begin{array}{c}39.0 \\
+16.83\end{array}$ & $\begin{array}{c}14 \\
(33.33 \%)\end{array}$ & $\begin{array}{c}10 \\
(23.81 \%)\end{array}$ & $\begin{array}{c}2 \\
(4.76 \%)\end{array}$ & $\begin{array}{c}7 \\
(16.67 \%)\end{array}$ & $\begin{array}{c}25 \\
(59.52 \%)\end{array}$ & $\begin{array}{c}9 \\
(21.43 \%)\end{array}$ & $\begin{array}{c}26 \\
(6.90 \%)\end{array}$ \\
\hline $\begin{array}{l}\text { Total } \\
(n=106)\end{array}$ & & $\begin{array}{c}38 \\
(35.85 \%)\end{array}$ & $\begin{array}{c}23 \\
(21.70 \%)\end{array}$ & $\begin{array}{c}7 \\
(6.60 \%)\end{array}$ & $\begin{array}{c}19 \\
(17.92 \%)\end{array}$ & $\begin{array}{c}73 \\
(68.87 \%)\end{array}$ & $\begin{array}{c}29 \\
(27.36 \%)\end{array}$ & $\begin{array}{c}61 \\
(57.55 \%)\end{array}$ \\
\hline
\end{tabular}

${ }^{\dagger}$ WBC and RBC count under high power dry objective (X 40) of the microscope. 
TABLE II:

FREE AMINO ACIDS MISSING IN URINE OF PATIENTS WITH UTI

(Total cases with percentage in which amino acids were missing in urine, $n=106$ )

\begin{tabular}{|l|c|c|}
\hline Amino Acid & $\begin{array}{c}\text { Urine of } \\
\text { Control }\end{array}$ & $\begin{array}{c}\text { Urine of } \\
\text { Patients }\end{array}$ \\
\hline Alanine & $0(0 \%)$ & $48(45.28 \%)$ \\
\hline Aspartic Acid & $1(4 \%)$ & $55(51.88 \%)$ \\
\hline Aspargine & $2(8 \%)$ & $6(5.66 \%)$ \\
\hline Cysteine & $0(0 \%)$ & $30(28.30 \%)$ \\
\hline Glycine & $0(0 \%)$ & $15(14.15 \%)$ \\
\hline Glutamic Acid & $4(16 \%)$ & $6(5.66 \%)$ \\
\hline Histidine & $2(8 \%)$ & $40(37.73 \%)$ \\
\hline$\bullet$ Isoleucine & $0(0 \%)$ & $70(66.03 \%)$ \\
\hline Lysine & $0(0 \%)$ & $33(31.13 \%)$ \\
\hline Leucine & $0(0 \%)$ & $47(44.33 \%)$ \\
\hline$\bullet$ Methionine & $0(0 \%)$ & $97(91.50 \%)$ \\
\hline$\bullet *$ Phenylalanine & $2(8 \%)$ & $76(71.69 \%)$ \\
\hline Proline & $2(8 \%)$ & $53(50 \%)$ \\
\hline Serine & $3(12 \%)$ & $32(30.18 \%)$ \\
\hline$\bullet *$ Tryptophan & $4(16 \%)$ & $96(90.56 \%)$ \\
\hline$\bullet *$ Tyrosine & $3(12 \%)$ & $75(70.75 \%)$ \\
\hline Threonine & $6(4 \%)$ & $9(8.49 \%)$ \\
\hline Valine & $0(0 \%)$ & $42(39.62 \%)$ \\
\hline
\end{tabular}

- Indicates essential amino acids

* Indicates aromatic amino acids

\section{DISCUSSION}

Most of the UTI patients received at Liaquat University Hospital Jamshoro and Hyderabad belong to adjoining rural areas of Sindh. The reasons for high frequency of UTI in this set up may be poor sanitation, lack of safe water supply and poor general hygienic conditions. Keeping in mind unreliable results of urinalysis and dipstick and non-availability of advanced diagnostic equipments, most of which are electrically operated and require highly trained and qualified staff, lack of diagnosis can be reason for improper usage of antibiotics by local doctors resulting in complications or masked picture when they reach city hospitals for proper treatment. It is well known fact that amino acids are increased in urine of UTI patients due to increase in the permeability of glomerular capillaries. Gill, et al
(2001) have reported missing amino-acids in urine of parasitic infested rats $^{13}$, may be due to consumption of amino acids by parasites. We planned to develop easy to do and easy to interpret method of paper chromatography using two solvents to avoid overlapping and looked for missing amino-acids in infected urine which may have been consumed by infecting bacterias. Different amino acids were found missing in urine of urinary tract infection patients especially aromatic amino acids like tryptophan in $90.56 \%$, phenylalanine $70.69 \%$ and tyrosine $70.75 \%$ as compared to aliphatic and hetrocyclic amino acids. Essential amino acids were also missing though in less percentage of cases except methionine $91.50 \%$. Different missing amino acids may be the choice of different bacterias infecting urinary tract. Non-essential amino acids were comparatively less missing, which may be because bacterias can prepare non-essential amino acids themselves. The findings in normal cases may indicate that these cases may be prone to develop infections or were in the initial stage of infection. Therefore, it is recommended to evaluate UTI screening on basis of missing amino acids.

\section{CONCLUSION}

Through this study, it has been tried to develop a simple method for initial diagnosis of UTI by paper chromatography. This can be made available in rural areas where no electric facility is available. Also, this test can be performed with less expertise and low cost. However, further large studies are recommended on different amino acids not present in blood and urine samples of UTI patients infected with particular type of bacteria.

\section{REFERENCES}

1. Wyatte T, Reilly P. Treating common infections. Practitioner. 1990; 234: 243-45.

2. Jones KV. Urinary tract infection in childhood. Practitioner. 1991;235:135-43.

3. Coonrod BA, Ellis D, Becker DS and Bunker $\mathrm{CH}$. Epidemiology of diabetes complication study diabetes care. 1993; 16: 1376-83.

4. Foster DW. Urinary tract infection. Harrison's Principles of Internal Medicine. Vol. 214. USA McGraw Hill Health Professions Division. 1998; Pp. 2060-81.

5. Hurlbut TA, Littenburg B. The diagnostic accuracy of rapid dipstick tests to predict urinary tract infections. Am J Clin Pathol. 1991; 96: 582-86.

6. Bonnarddeaux A, Sonmerville P, Kaye M. A study on the reliability of dipstick urinalysis. Clin Nephrol. 1994; 41:167-72.

7. Rehmani R. Accuracy of urine dipstick to predict urinary tract infections in an emergency depart- 
ment. J Ayub Med Coll Abbottabad. 2004; 16(1): 4-7.

8. Ohly N. Teece S. Accuracy of negative dipstick urine analysis in ruling out urinary tract infection in adults. Emerg Med J. 2003; 20(4):362-63.

9. Press SM, Smith AD. Incidence of negative heamaturia in patients with accurate urinary lithiasis presenting to the emergency room with flank pain. Urology. 1995; 5(5):753-57.

10. Propp DA, Weber D, Ciesla ML. Reliability of a urine dipstick in emergency department patients Ann Emerg Med. 1989;18(5):560-63.

11. Colle JG, Duguid JP, Fraser AG, Marmion BP. (Eds) Practical Medical Microbiology. $13^{\text {th }}$ Edition. Edinburgh; Churchill Livingstone. 1989.

12. Wright AR, Reller BL. The patients with urinary tract infection. In: Manual of Nephrology. ${ }^{\text {rd }}$ Edition. London: Little Brown and Company. 1986: Pp.111- 17.

13. Gill N, Memon MS and Khan M. Plasma free amino acid level in Rats with parasitic infestation. J Biolog Sci. 2001; 96:764-67.
14. Ames Multireagent Strip,Ames Division, Miles Inc. USA, Division of Bayer Diagnostics, Division of Bayer Australia limited.

15. Cheetham P, Brown SE. Technique for the culture and direct sensitivity testing of large numbers of urine specimens. J Clin Path. 1986; 39: 335-37.

16. Maskell R. Urine microscopy and culture in selection of patients for urinary tract investigation. $\mathrm{Br} \mathrm{J}$ Urol. 1989; 63: 7 - 10.

17. Lowe PA. Chemical screening and prediction of bacteriuria; a new approach. Med Lab Sc. 1986;43:28-33.

18. Knowrower S. Phenylketonuria and amino acid disorders. Chemistry and functions of amino acids. 2nd Edition. New York, Academic Press Inc. 1968. Pp. 315-18.

19. Egon S. Thin layer chromatography. 2nd Edition. New York, Springer - Veriag. 1969; Pp. 740-745.

20. Stock and Rice. Chromatography methods. $3^{\text {rd }}$ Edition, Chapman and Hall Ltd. 1974; Pp.339-63.

\begin{tabular}{|l|}
\hline AUTHOR AFFILIATION: \\
Dr. Muhammad Ali Memon \\
Assistant Professor \\
Department of Biochemistry \\
Liaquat University of Medical \& Health Sciences \\
Jamshoro, Sindh. \\
Prof. Habibullah Qureshi (Corresponding Author) \\
Department of Biochemistry \\
Muhammad Medical College (MMC), Mirpurkhas, Sindh. \\
Prof. M. Saleh Memon \\
Department of Biochemistry \\
MMC Mirpurkhas, Sindh.
\end{tabular}

